\title{
Influence of climatic conditions on in vitro production of bovine embryos
}

\author{
[Influência do clima na produção in vitro de embriões bovinos] \\ G.A. Pessoa, R.B. Navarro, L.P. Rauber, K.E. Brass, C.A.M. Silva, M.I.B. Rubin \\ Embryolab - Laboratório de Embriologia Animal \\ Departamento de Clínica de Grandes Animais \\ Centro de Ciências Rurais - UFSM \\ 97105-900 - Santa Maria, RS
}

\begin{abstract}
Temperature and rainfall were analyzed daily during six years to evaluate their influence on in vitro production of bovine embryos. Weekly replications $(n=480)$ were performed on 14,778 ovaries collected at slaughterhouses. Cumulus oocyte complexes $(n=19,180)$ were fertilized with a pool of Bos taurus taurus semen in one incubator with $5 \% \mathrm{CO}_{2}$. Presumable zygotes were cultured in gasified plastic bags with $5 \% \mathrm{CO}_{2}, 5 \% \mathrm{O}_{2}$, and $90 \% \mathrm{~N}_{2}$. In the first year, cleavage and embryo yield were $60.3 \%$ and $15.6 \%$, respectively, being lower $(\mathrm{P}<0.05)$ than in the following years. Average cleavage rates were always lower in winter $(\mathrm{P}<0.0001)$, thus producing less embryos. Winter climatic conditions had a negative influence on in vitro production, when cleavage and embryo yield declined, possibly because of reduced availability and growth of native pasture.
\end{abstract}

Keywords: cow, oocytes, embryo, climate, in vitro prodution

\section{RESUMO}

A temperatura e a precipitação pluviométrica foram analisadas diariamente, durante seis anos, para avaliar sua influência sobre a produção in vitro de embriões bovinos. As repetições semanais $(n=480)$ foram realizadas com 14.778 ovários coletados em matadouros. Os oócitos $(\mathrm{n}=19.180)$ foram maturados em estufa com atmosfera com controle de temperatura e umidade saturada com $5 \%$ de $\mathrm{CO}_{2}$ e, após $20 \mathrm{~h}$, foram fecundados com sêmen de Bos taurus taurus e mantidos sob as mesmas condições de atmosfera da maturação. Os zigotos foram cultivados em placas de quatro poços em bolsas gaseificadas com $5 \%$ de $\mathrm{CO} 2,5 \%$ de $\mathrm{O}_{2}$ e $90 \%$ de $\mathrm{N}_{2}$, à temperatura de $39^{\circ} \mathrm{C}$ e umidade saturada. No primeiro ano, a taxa clivagem $(60,3 \%)$ e a produção de embriões $(15,6 \%)$ foram inferiores $(\mathrm{P}<0,05)$ aos demais anos. As taxas de clivagem foram sempre menores no inverno $(\mathrm{P}<0,0001)$. As condições climáticas no inverno tiveram influência negativa sobre a produção in vitro de embriões bovinos e houve diminuição nos índices de clivagem e produção de blastocistos, possivelmente devido à reduzida disponibilidade e crescimento da pastagem nativa.

Palavras-chave: bovino, ovócitos, embriões, clima, produção in vitro

\section{INTRODUCTION}

In vitro production (IVP) of bovine embryos comprises the steps of maturation (IVM), fertilization (IVF), and culture (IVC). This biotechnology has been used in Brazil since 1990 (Oliveira et al., 1994) as a tool for the multiplication of animals with high genetic value and for cloning and transgenic animal production. Therefore, IVP is important in the scientific arena as well as in the industry. The native vegetation (Biome Pampa) of Rio Grande do Sul (RS) is also known as savannah, with the subtypes: shrubs and trees, and steppe (Quadros et al., 2003). The climate ensues a marked seasonality in the native pasture growth

Recebido em 20 de abril de 2010

Aceito em 15 de dezembro de 2010

E-mail: gilsonpessoavet@yahoo.com.br 
(Carvalho, 2009). The extensive management of animals on wide grazing areas reduces the productivity of the herd, in weight gain, and reproductive function. During the cold season in the southern hemisphere (May-September), the impairment on the growth of tropical forage plants is greater because of the occurrence of frost and irregular rainfall, resulting in a lower rate of forage accumulation, and consequently, lower daily average of body weight gain (Soares et al., 2005).

Environmental influences such as temperature, seasonality, and nutritional management interfere with reproductive efficiency, follicular development, and oocyte quality, and consequently, fertility (Webb, 1998; Armstrong et al., 2001; Webb et al., 2004). Environmental conditions and diets that are appropriate for follicular growth may not necessarily be appropriate for oocyte quality (Webb et al., 2004). Several studies demonstrate that nutritional and metabolic signals influence ovarian function by modulating the secretion of gonadotropins by the hypothalamic-pituitary axis (Gong, 2002). These observations focused on determining the nutritional influence on reproductive function mediated by the ovaries (Robinson et al., 2006).

The aim of this study was to analyze the potential influence of environment on bovine in vitro embryo production.

\section{MATERIAL AND METHODS}

Monthly measurements of temperature and rainfall in the central region of Rio Grande do Sul state (RS), Brazil, were performed during six years (2002-2007) by the Automatic Weather Monitoring Station at the Instituto Nacional de Meteorologia (INMET, A803) latitude 2943'S, longitude $53^{\circ} 43^{\prime} \mathrm{W}$, and altitude $95 \mathrm{~m}$.

During all year around, for a period of 6 years, 480 replicates were performed to produce bovine embryos in vitro. Cumulus oocyte complexes (COC) were recovered from 14,778 ovaries of crossbred slaughtered cows (Bos taurus indicus $\mathrm{x}$ Bos taurus taurus) raised in Rio Grande do Sul, Brazil (latitude $29.00^{\circ}$ to $31.00^{\circ} \mathrm{S}$ and longitude $52.00^{\circ}$ to $54.00^{\circ} \mathrm{W}$ ). The ovaries collected at slaughterhouses were kept in $0.9 \%$ saline solution at $30-35^{\circ} \mathrm{C}$ during the transport of 22 to $92 \mathrm{~km}$ to the laboratory.

The COC were recovered by aspiration of 2$8 \mathrm{~mm}$ diameter follicles with an 18G needle connected to a vacuum pump (pressure $20 \mathrm{~mL} / \mathrm{min}$ ). Cumulus oocyte complex selection was performed in follicular fluid (Lehmkul et al., 2000) under a stereomicroscope, and they were classified according to cumulus morphology (De Loos et al., 1989) into homogenous compact cytoplasm with unexpanded cumulus and expanded cumulus. The COC with unexpanded cumulus were randomly assigned to maturation and the expanded ones were discarded.

Immature COC $(n=19,180)$ were cultured in four-well Nunc ${ }^{\circledR}$ dishes (Nunc Brand Prod. Roskilde, Denmark) containing $400 \mu \mathrm{L}$ of TCM 199 (GIBCO BRL, 31100-27 - Grand Island, USA) maturation medium supplemented with 26.2mM $\mathrm{NaHCO}_{3}(\mathrm{~S} 5761), \quad 25 \mathrm{mM}$ hepes (H6147), 0.2mM sodium pyruvate (P4562), $0.5 \mu \mathrm{g} / \mathrm{mL}$ FSH (Folltropin-V, Bioniche Animal Health - Ontario, Canada), $10 \mu \mathrm{g} / \mathrm{mL}$ LH (Lutrophin-V, Bioniche Animal Health), and $10 \%$ estrous mare serum (EMS; Embryolab, UFSM - Santa Maria, RS, Brazil). In vitro maturation was performed in an incubator (W.C Heraeus $\mathrm{GmbH}-\mathrm{Hanau}$, Germany) at $38^{\circ} \mathrm{C}, 5 \%$ $\mathrm{CO}_{2}$ atmosphere, and 95\% humidity for 18 to 20h. The oocytes (mean of 20 oocytes/well) were randomly distributed among experimental groups in all replicates. Except as otherwise indicated, all chemical components were acquired from Sigma Chemical Co. (St. Louis - USA).

In vitro fertilization was performed with a pool of proved frozen semen from Bos taurus taurus bulls. After thawing semen in a water bath at $38^{\circ} \mathrm{C}$ for 30 seconds, the sperm was selected by swim up in Sperm-Talp medium (Parrish et al., 1995) with addition of $0.06 \mathrm{mg} / \mathrm{mL}$ bovine serum albumin (BSA; A331) and $0.11 \mathrm{mg} / \mathrm{mL}$ sodium pyruvate. After maturation, oocytes were transfered to four-well Nunc dishes containing $400 \mu \mathrm{L}$ Fert-Talp with $0.06 \mathrm{mg} / \mathrm{mL}$ bovine serum albumin (BSA) and $0.022 \mathrm{mg} / \mathrm{mL}$ sodium pyruvate supplemented with $50 \mu \mathrm{g} / \mathrm{mL}$ heparin (H3393). Oocytes were inseminated with 1 to $2 \times 10^{6}$ sperm $/ \mathrm{mL}$ and maintained at $38^{\circ} \mathrm{C}$ with $5 \% \mathrm{CO}_{2}$ in saturated humidity for 18 to $22 \mathrm{~h}$. 
Zygotes were vortexed for 90 seconds and washed in $100 \mu \mathrm{L}$ drops of TCM-HEPES. Then, they were transfered for culture to $400 \mu \mathrm{L}$ SOFaaci medium (Holm et al., 1999) supplemented with 5\% EMS and $0.022 \mathrm{mg} / \mathrm{mL}$ sodium pyruvate, covered with $300 \mu \mathrm{L}$ mineral oil (M5904), previously stabilized in the incubator at $38^{\circ} \mathrm{C}$ with $5 \% \mathrm{CO}_{2}$ and saturated humidity. On day 2 (D2) of culture (D0 = fertilization day), the cleavage rate was assessed by the identification of cell division. Embryo culture was performed for four days in a foil bag system similar to the culture system described by Vajta et al. (1997) under an atmosphere of 5\% $\mathrm{CO}_{2}, 5 \% \mathrm{O}_{2}$ and $90 \% \mathrm{~N}_{2}$. On day 7 (D7) of culture, embryos were evaluated and classified according to quality and development stage following IETS criteria.

The influence of temperature and rainfall was evaluated by correlation and regression analysis. Cleavage and blastocyst yield were analyzed by variance analysis. Graphics were produced by GraphPad Prism 5. Data were processed using SAS 9.1 statistical program. Differences were considered significant at $\mathrm{P}<0.05$.

\section{RESULTS}

The climate in the central region of the RS state is characterized by average monthly temperatures below $17^{\circ} \mathrm{C}$ from middle Autumn to the end of Winter (May-September) with frequent occurrence of frost in July and August. The average monthly temperatures from spring to summer (October-March) stay above $19^{\circ} \mathrm{C}$ (Figure 1A).

The annual temperature variation during the study period did not changed $(\mathrm{P}=0.1293)$ and total rainfall (Figure 1B) differed between 2002 and $2004(\mathrm{P}=0.0001), 2002-2005 \quad(\mathrm{P}=0.0001)$, 2002-2006 ( $\mathrm{P}=0.0003), 2002-2007 \quad(\mathrm{P}=0.0065)$, 2003-2004 (P=0.0194), and 2004-2007 $(\mathrm{P}=0.0036)$. The average annual precipitation volume ranged from $1500 \mathrm{~mm}$ to $2200 \mathrm{~mm}$. The annual rainfall was considered below average in the years of $2004(1.065 \mathrm{~mm}), 2005(1.332 \mathrm{~mm})$, and $2006(1.315 \mathrm{~mm})$.

The excessive rainfall observed in 2002 (Fig. 1B) associated with low luminosity and low winter temperature may have negatively influenced the quality of native and cultivated forages. This was reflected in a lower cleavage rate (60.3\%) in comparison to the one obtained in the years of 2006 (77.0\%, $\mathrm{P}=0.01980)$ and 2007 (79.2\%, $\mathrm{P}=0.0072$ ), periods when rainfall was well distributed throughout the four seasons. The IVP of bovine embryos in 2002 (15.6\%) also remained below the rates obtained the other years; however, differed $(\mathrm{P}=0.0011)$ only from the IVP of 2007. The average cleavage of the bovine oocytes was evaluated during six years (Figure 1C) and lower rates (60\%; $\mathrm{P}<0.0001)$ were observed in winter (July-August). Figure $1 \mathrm{D}$ shows the decrease in blastocyst yield in winter (July-August) (16\% vs 23\%, respectively, $\mathrm{P}=0.0084$ ), denoting a significant correlation between average monthly temperature during the seasons and cleavage rate $\left(R^{2}=0.8386\right.$, $\mathrm{P}<0.0001$ ), and, consequently, embryo production on D7 $\left(R^{2}=0.3456, \mathrm{P}=0.0444\right)$.

Cleavage (Figure 2A) and the IVP rates on D7 (Figure 2B) of the four seasons during six years highlights a reduction during the winter months.

\section{DISCUSSION}

The average annual precipitation volume was one factor that might have influenced the growth of natural and cultivated pastures. Flooding of the soil by intense rain can lead to reduction in the rate of carbohydrates, translocation from leaves to roots, reduced growth and metabolic activity of roots (Dias-Filho, 2005) and, consequently, lower nutritional quality of pasture.

The decreased accumulation of forage and increased amount of fibers found in pasture from autumn to winter (April-September) is mainly due to the low temperatures, luminosity, and frost characteristic of the climate. This reflects the seasonal production of native pasture in the region (Soares et al., 2005). During this study period, the lowest rainfall volume occurred from summer to late winter (January-August). This reduces the growth rate of native forage and changes the bromatological characteristics (Castro et al., 1997). 


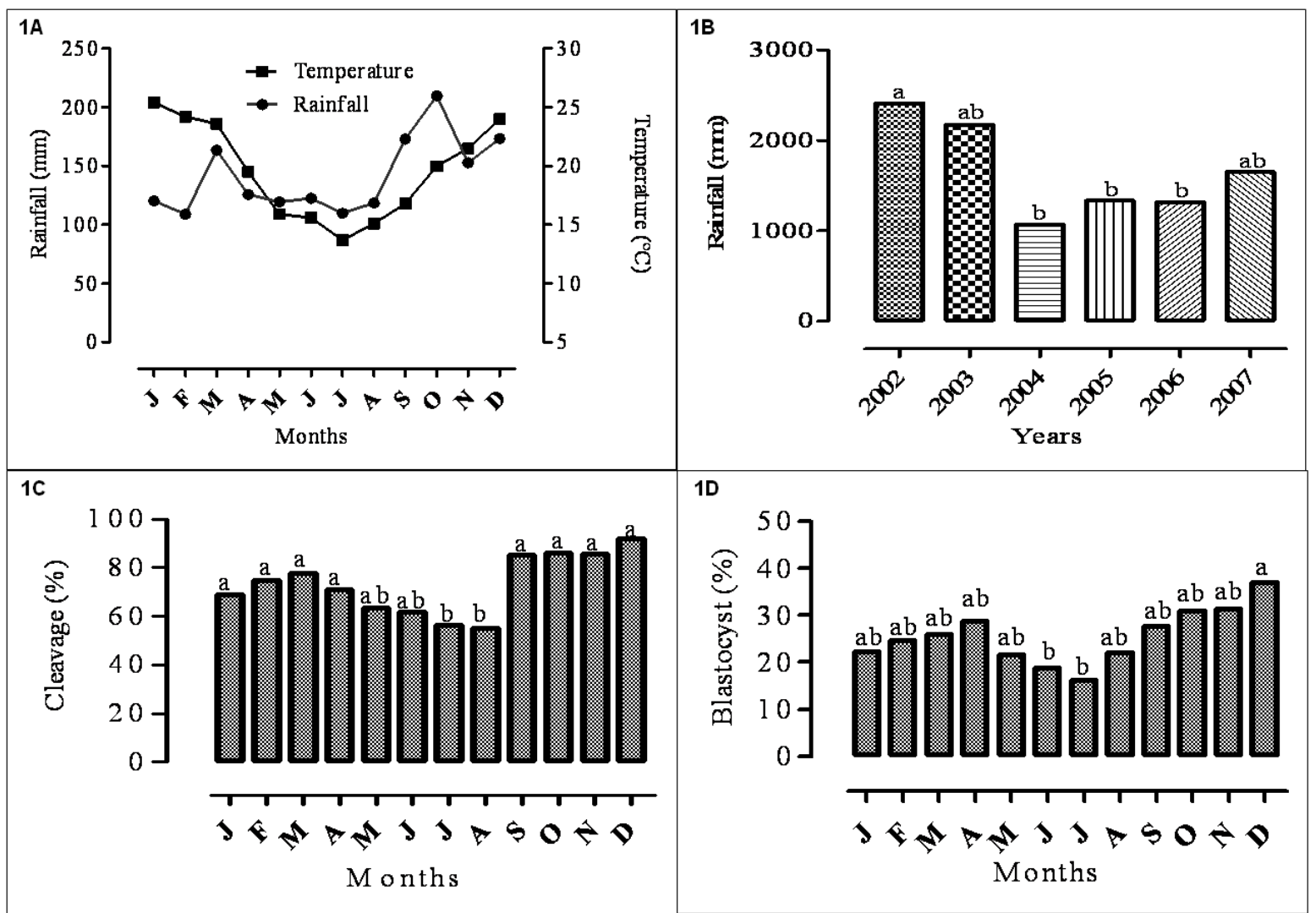

Figure 1. 1A- Average monthly rainfall and temperatures registered from 2002 to 2007 by the Automatic Weather Monitoring Station (A803). 1B- Annual rainfall from 2002 to 2007 (A803). 1C- Average monthly cleavage rate of in vitro fertilized bovine oocytes from 2002 to 2007. 1D- Average monthly embryo production rate (D7) from 2002 to 2007. Same letters above columns indicate no significant difference $(\mathrm{P}<0.05)$

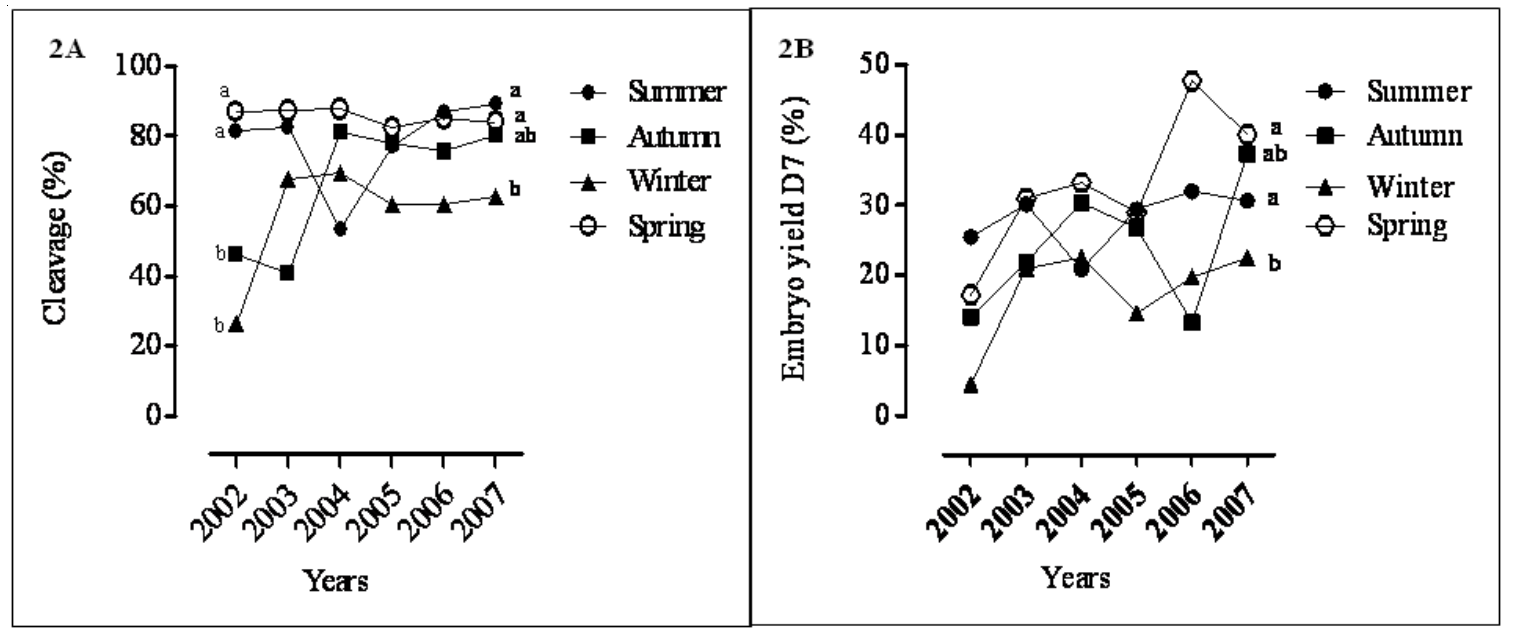

Figure 2. 2A- Cleavage rate of in vitro fertilized bovine oocytes from 2002 to 2007. 2B- In vitro production rate of bovine embryos (D7) from 2002 to 2007. 
The negative impact on animal weight gain occur essentially during the winter months (June to August) due to the reduced availability and decreased growth of native pasture consequent to the low environmental temperature (Soares et al., 2006; Carvalho, 2009).

The weight loss in cows impairs the hormonal production at the hypothalamic-pituitary axis, the ovarian follicular growth (Adamiak et al., 2005), and oocyte quality (Lequarre et al., 2005). The most efficient test to assess oocyte quality is their ability to be fertilized, and to develop into the blastocyst stage (Lonergan et al., 2001). Thus, the most reliable parameter for oocyte quality evaluation is its competence to develop in vitro, and reach the first cleavage (Vam Soom et al., 1992). This finding is supported by the research of Van Soom et al. (1992) showing that oocyte quality and subsequent cleavage is influenced by the metabolic conditions of the donor. The cows whose ovaries were used in this study were grazing on native pastures during winter. The low availability of forage during this season results in gradual weight loss (Carvalho, 2009).

Weight loss negatively affects growth rate and ovulatory follicle size, resulting in changes in oocyte competence and development by low plasmatic glucose concentrations (O’Callaghan and Boland, 1999; Adamiak et al., 2005). Glucose is the primary metabolic fuel used by the central nervous system, and inadequate availability of glucose reduces hypothalamic release of GnRH (Keisler and Lucy, 1996; Wettemann et al., 2003). The ability of beef cows to maintain fairly constant concentrations of blood glucose, however, has prompted some reviewers to suggest that the role of glucose in mediating nutritional control of reproduction is permissive rather than causative (Schillo, 1992; Keisler and Lucy, 1996). This effect is probably due to the biological ability to store nutrients during the seasons of higher pasture availability for maintenance of physiological activity under adverse conditions (Armstrong e Evans, 1983). Low blood glucose may be detected by the hypothalamus in a threshold-dependent manner such that GnRH secretion will be impaired if glucose availability is inadequate (Randel, 1990; Dhuyvetter and Caton, 1996).
Thus, the reduction in cleavage and blastocyst yield during the cold season (July-August) may be an effect of low availability of native pasture growth during winter. Decrease in the cleavage rate from $79 \%$ to $64 \%$ was observed in sheep subjected to in vitro production with food restriction (O’Callaghan and Boland, 1999; Borowczyk et al., 2006). This finding corroborates with studies in cattle, in which ovaries were obtained from slaughtered cows under feed restriction during the cold season. Cows with low body score due to food restriction have lower levels of insulin growth factor-1 (IGF-I) and lower number of follicles larger than $8 \mathrm{~mm}$, compared to cows not exposed to food restriction (Boland et al., 2001; Gong, 2002; Adamiak et al., 2005).

Low IGF-1 levels increase the responsiveness of the ovarian follicle to FSH (Armstrong et al., 2001). In contrast, high dietary carbohydrate intake increases the concentration of circulating insulin and IGF-1, improving rate the growth of the dominant follicle.In females with decreased glucose levels, oocyte quality is directly affected and this is reflected by lower cleavage rates (Sutton et al., 2003). The glucose in oocytes is predominantly metabolized via the pentose phosphatase pathway for synthesis of DNA and RNA (Sutton-McDowall et al., 2004). Thus, maternal mRNA and protein molecules are synthesized and accumulated during oocyte growth and maturation, which are essential to ensure the embryo survival until the stage of 816 cells (Lonergan et al., 2003).

\section{CONCLUSIONS}

Extragonadal factors such as seasonal climatic changes, food intake, and nutritional status of the animals are correlated with IVP of bovine embryos. The decline in food supply available during the winter season leads to weight loss and impairs endocrine reproductive function. This correlation between climatic changes and reproductive parameters has been shown evaluating cleavage and blastocyst yield of in vitro produced bovine oocytes during the months of lower availability of native pasture. 


\section{ACKNOWLEDGMENTS}

The authors thank Dr. Arno Bernardo Heldwein from the Departamento de Fitotecnia (UFSM Santa Maria, RS) for his valuable comments and suggestions and INMET for data availability.

\section{REFERENCES}

ADAMIAK, S.J.; MACKIE, K.; WATT, R.G. et al. Impact of nutrition on oocyte quality: cumulative effects of body composition and diet leading to hyperinsulinemia in cattle. Biol. Reprod., v.73, p.918-926, 2005.

ARMSTRONG, D.G.; McEVOY, T.G.; BAXTER, G. Effect of dietary energy and protein on bovine follicular dynamics and embryo production in vitro: associations with the ovarian insulin-like growth factor system. Biol. Reprod., v.64, p.1624-1632, 2001.

ARMSTRONG, D.T.; EVANS, G.M. Factors influencing success of embryo transfer in sheep and goats. Theriogenology, v.19, p. 31-42, 1983.

BOLAND, M.P.; LONERGAN, P.; O'CALLAGHAN, D. Effect of nutrition on endocrine parameters, ovarian physiology, and oocyte and embryo development. Theriogenology, v.55, p.1323-1340, 2001.

BOROWCZYK, E.; CATON, J.S.; REDMER, D.A. et al. Effects of plane of nutrition on in vitro fertilization and early embryonic development in sheep. J. Anim. Sci., v.84, p.1593-1599, 2006.

CARVALHO, P.C.F. Pasture country profile: Brazil. Plant production and protection division. Available from: $<$ http://www.fao.org/ag/AGP/AGPC/doc/counpr of/Brazil.htm/>. Last accessed: May 6, 2009.

CASTRO, C.R.T.; CARVALHO, M.M.; GARCIA, R. Produção forrageira e alterações morfológicas em gramíneas cultivadas sob luminosidade reduzida. In: REUNIÃO ANUAL DA SOCIEDADE BRASILEIRA DE ZOOTECNIA, 1997. Juiz de Fora. Anais..., Juiz de Fora: SBZ, 1997. p.338-340.

De LOOS, F.; Van VLIET, C.; Van MAURIK, P. et al. Morphology of immature bovine oocytes. Gamete Res., v.24, p.197-204, 1989.
DHUYVETTER, D.V.; CATON, J.S. Manipulation of reproduction and lactation with supplementation in beef cattle. In: JUDKINS, M.B.; McCOL-LUM, F.T. (Eds). Proc. GRAZING LIVESTOCK NUTRITION CONFERENCE, 3., 1996. Proc. West. Sec. Am. Soc. Anim. Sci., v.47, suppl.1, p.83-93, 1996.

DIAS-FILHO, M.B. Opções forrageiras para áreas sujeitas a inundação ou alagamento temporário. In: PEDREIRA, C.G.S.; MOURA, J.C.; SILVA, S.C. et al. (Eds). Teoria e prática da produção animal em pastagens. In: SIMPÓSIO SOBRE MANEJO DE PASTAGEM. 22., 2005, Piracicaba. Anais... Piracicaba: FEALQ, 2005. v.1, p.71-93.

GONG, J.G. Influence of metabolic hormones and nutrition on ovarian follicle development in cattle: practical implications. Domest. Anim. Endocrinol., v.23, p.229-241, 2002.

HOLM, P.; BOOTH, P.J.; SCHMIDT, M.H. et al. High bovine blastocyst development in a static in vitro production system using SOFaaci medium supplemented with sodium citrate and myo-inositol with or without serum proteins. Theriogenology, v.52, p.683-700, 1999.

KEISLER, D.H.; LUCY, M.C. Perception and interpretationof the effects of undernutrition on reproduction. J. Anim. Sci., v.74, suppl.3, p.1-17, 1996.

LEHMKUL, R.C.; MEZZALIRA, A.; VIEIRA, A.D. et al. Desenvolvimento de oócitos bovinos mantidos em líquido folicular e submetidos a FIV. Arq. Fac. Vet. UFRGS, v.28, p.276, 2000.

LEQUARRE, A.S.; VIGNERON, C.; RIBAUCOUR, $F$. et al. Influence of antral follicle size on oocyte characteristics and embryo development in the bovine. Theriogenology, v.63, p.841-859, 2005.

LONERGAN, P.; RIZOS, D.; WARD, F. et al. Factor's influencing oocyte and embryo quality in cattle. Reprod. Nutr. Dev., v.41, p.427-437, 2001.

LONERGAN, P.; RIZOS, D.; GUTIERREZADAN, A. et al. Oocyte and embryo quality: effect of origin, and culture conditions and gene expression patterns. Reprod. Domest. Anim., v.38, p.259-267, 2003. 
O’CALLAGHAN, D.; BOLAND, M. Nutritional effects on ovulation, embryo development and the establishment of pregnancy in ruminants. Anim. Sci., v.68, p.299-314, 1999.

OLIVEIRA, E.B.; WATANABE, Y.F.; GARCIA, J.M. Establishment of IVF program for Zebu cattle (Bos indicus) in Brazil. Theriogenology, v.41, p.188, 1994.

PARRISH, J.J.; KROGENAES, A.; SUSKOPARRISH, J.L. Effect of bovine sperm separation by either swim-up or Percoll method on success of in vitro fertilization and early embryonic development. Theriogenology, v.44, p.859-869, 1995.

QUADROS, F.L.F.; BICA, G.S.; DAMÉ, P.R.V. et al. Levantamento das pastagens naturais da região de Santa Maria-RS, Brasil. Cienc. Rural, v.33, p.921-927, 2003.

RANDEL, R.D. Nutrition and postpartum rebreeding in cattle. J. Anim. Sci., v.68, p.853862, 1990.

ROBINSON, J.J.; ASHWORTH, C.J.; ROOKE, J.A. et al. Nutrition and fertility in ruminant livestock. Anim. Feed Sci. Technol., v.126, p.259-276, 2006.

SCHILLO, K.K. Effects of dietary energy on control of luteinizing hormone secretion in cattle and sheep. J. Anim. Sci., v.70, p.1271-1282, 1992.

SOARES, A.B.; CARVALHO, P.C.F.; NABINGER, C. et al. Produção animal e de forragem em pastagem nativa submetida a distintas ofertas de forragem. Cienc. Rural, v.35, p.1148-1154, 2005.

SOARES, A.B.; MEZZALIRA, J.C.; BUENO, E.M.C. et al. Efeitos de diferentes intensidades de pastejo em pastagem nativa melhorada sobre o desempenho animal. Rev. Bras. Zootec., v.35, p.75-83, 2006.
SUTTON, M.L.; GILCHRIST, R.B.; THOMPSON, J.G. Effects of in vivo and in vitro environments on the metabolism of the cumulusoocyte complex and its influence on oocyte developmental capacity. Hum. Reprod. Update, v.9, p.35-48, 2003.

SUTTON-McDOWALL, M.L.; GILCHRIST, R.B.; THOMPSON, J.G. Cumulus expansion and glucose utilization by bovine cumulus-oocyte complexes during in vitro maturation: the influence of glucosamine and follicle-stimulating hormone. Reproduction, v.128, p.313-319, 2004.

VAJTA, G.; HOLM, P.; GREVE, T. et al. The submarine incubation system, a new tool for in vitro embryo culture: a technique report. Theriogenology, v.48, p.1379-1385, 1997.

VAN SOOM, A.; VAN VLAENDEREN, I.; MAHMOUDZADEH, A.R. et al. Compaction rate of in vitro fertilized bovine embryos related to the interval from insemination to first cleavage. Theriogenology, v.38, p.905-919, 1992.

WEBB, R.; GARNSWORTHY, P.C.; GONG, J.G. et al. Control of follicular growth: Local interactions and nutritional influences. J. Anim. Sci., v.82, p.E63-E74, 2004.

WEBB, R. Control of ovarian function; effect of local interactions and environmental influences on follicular turnover in cattle: a review. Livest. Prod. Sci., v.53, p.95-112, 1998.

WETTEMANN, R.P.; LENTS, C.A.; CICCIOLI, N.H. et al. Nutritional- and suckling-mediated anovulation in beef cows. J. Anim. Sci., v.81, suppl.2, p.E48-E59, 2003. 